\title{
Selenyum Uygulamalarının Silajılık Mısırın Verim Parametreleri Üzerine Etkileri
}

\author{
Aișe DELIBORAN ${ }^{1}$ * Yılmaz IȘIK² Hasan ASLAN² Abdullah SUAT NACAR² \\ Tuba Yasemin TEKGÜL ${ }^{2}$ Hatice KARA² Sait GEZGIN ${ }^{3}$ \\ 'Zeytincilik Araștırma Enstitüsü Müdürlüğü, Toprak ve Su Kaynakları Bölümü, İzmir. \\ ${ }^{2}$ GAP Tarımsal Araștırma Enstitüsü Müdürlüğü, Șanlıurfa. \\ 35elçuk Üniversitesi, Ziraat Fakültesi, Toprak ve Bitki Besleme Bölümü, Konya.
}

\begin{abstract}
*Sorumlu yazar e-mail (Corresponding author e-mail): aisedeliboran@gmail.com
Geliș tarihi (Received) : 22.05.2019

Kabul tarihi (Accepted): 02.10.2020

DOI: $10.21657 /$ topraksu.741443
\end{abstract}

\section{Öz}

Bu çalıșmada sodyum selenit ve sodyum selenat uygulamalarının, silajlık mısır bitkisinin bitki boyu, koçan/bitki oranı, yaprak/sap oranı gibi bazı bitkisel özellikleri üzerine etkisi incelenmiștir. Selenyum sekiz farklı seviyede (0-5-1 0-1 5-25-50-75-100 $\mathrm{g} \mathrm{Se} \mathrm{ha-1)} \mathrm{uygulanmıștır.} \mathrm{Selenit,} \mathrm{tohum} \mathrm{ekiminden} \mathrm{önce} \mathrm{toprağa}$ sıvı halde, selenat ise mısır bitkisi 50-70 cm boyuna geldiğinde yapraktan uygulanmıștır. Selenyum uygulamaları yatma, bitki görünümü, kurtlu koçan sayısı, rastıkı bitki sayısı ve bitki boyu değerlerini istatistiksel olarak etkilememiștir. Selenit uygulamaları istatistiksel açıdan koçan/bitki oranı ile yaprak/sap oranı değerlerini etkilemiștir, yıl X konu interaksiyonu önemli çıkmıștır. 2013 yılında konular arasında istatistiki yönden fark olușmuș, en yüksek değerler sırasıyla \% 52 ile $5 \mathrm{~g}$ Se ha-1 uygulaması ile \% 45 ve $\% 47$ ile $10 \mathrm{~g} \mathrm{Se} \mathrm{ha}^{-1}$ ve $25 \mathrm{~g} \mathrm{Se} \mathrm{ha}^{-1}$ uygulamalarından elde edilmiștir. Selenat uygulamaları koçan/bitki oranı değerleri istatistiksel olarak etkilemezken yaprak/sap oranlarını etkilemiș, en yüksek değerler \% 43 ile $100 \mathrm{~g} \mathrm{Se} \mathrm{ha}^{-1}$ uygulamalarından elde edilmiștir. Selenyum uygulamalarının bitkilerde verimi ve diğer bitkisel özellikleri etkilemediği, tanenin veya bitkinin selenyum konsantrasyonunu etkileyerek arttırdığı bilinmektedir. Ancak bazı çalıșmalar selenyum uygulamasının bitkiyi olumlu etkilediğini göstermektedir. Bitki gelișiminde selenyum etkisinin bitki türüne ve çeșidine bağı olarak değișebileceği, birçok faktörün selenyum etkinliğini arttırarak etkilediği, özellikle toprak ve iklim koșullarının dıșında uygulama zamanı, oranı ve metodu ile selenyum formu ve bitki türünün etkili olduğu düșünülmektedir.

Anahtar Kelimeler: Mısır, selenyum, toprak uygulaması, yaprak uygulaması, verim parametreleri

\section{The Effect of Selenium Applications on Yield Parameters of Silage Maize}

\begin{abstract}
In this study, the effects of sodium selenite and sodium selenate applications on laying, plant appearance, number of worm cobs, random number of plants, plant height, cob/plant ratio, leaf/stem ratio of silage maize plant were investigated. Selenium was applied at eight different levels (0-5-10-15-2550-75-100 $\left.\mathrm{g} \mathrm{Se} \mathrm{ha}^{-1}\right)$. Selenite was applied to the soil in liquid form before planting seeds, and selenate was applied to the leaf when the corn plant was $50-70 \mathrm{~cm}$ tall. Selenium applications did not statistically affect lying, plant appearance, worm cob number, randomized plant number and plant height values. Selenite applications affected the cob/plant ratio and leaf/stem ratio values statistically, the interaction of the year $X$ subject was significant. In 2013, there was a statistical difference between the subjects, the
\end{abstract}


highest values were obtained with 52\% from $5 \mathrm{~g} \mathrm{Se} \mathrm{ha}^{-1}$ application, with 45\% and 47\% from $10 \mathrm{~g}$ Se $\mathrm{ha}^{-1}$ and $25 \mathrm{~g} \mathrm{Se} \mathrm{ha-1}$ applications, respectively. Selenate applications did not affect the cob/plant ratio values statistically, but the leaf/stem ratios were affected, the highest values were obtained with 43\% from $100 \mathrm{~g} \mathrm{Se} \mathrm{ha}^{-1}$ applications. It is known that selenium applications do not affect the yield and other plant properties in plants, but increase the selenium concentration of the grain or plant. However, some studies show that selenium application affects positively the plant as our study. It is thought that the effect of selenium in plant development may vary depending on the type and variety of the plant, many factors increase the selenium activity, especially outside the soil and climatic conditions, the application time, rate and method, the form of selenium and the plant species are effective.

Keywords: Maize, selenium, soil application, foliar application, yield parameters

\section{Gíriș}

Birim alandan elde edilen yeșil ot veriminin fazla olması ve silaj yapımına uygunluğu, silajın besin değeri ve lezzetinin yüksekliği gibi birçok nedenden dolayı mısır dünya da en önemli silaj bitkilerinden biri olarak yerini almıștır (Açıkgöz, 1991). Özellikle mısır hasılının çok kolay silolanabilir bir özelliğe sahip olması (Ak ve Doğan, 1997), sindirilme oranının yüksekliğinin yanı sıra birim alandan alınan verimin yüksek olması nedeniyle mısır, en ideal silaj bitkisi olarak kabul edilmiștir (Açıkgöz, 2001). Mısır silajı Amerika Birleșik Devletleri, Hollanda, Almanya ve Fransa gibi ülkelerde özellikle sığır besiciliğinde yoğun olarak kullanılmaktadır (Klıç, 1986; 1996; Gökçe, 2000; Alçiçek ve Karaayvaz, 2003). Üretim bakımından dünyada buğdaydan sonra ikinci, Türkiye'de ise buğday ve arpadan sonra üçüncü sırada yer alan (TUiK, 2014) mısır, ekim alanı bakımından Türkiye dünyada mısır üreticisi 157 ülke arasında 34., üretim bakımından 25. ve birim alan verimi bakımından ise 40. ülke durumundadır (FAO, 2014). Türkiye'de tane mısırın ekim alanı 6.599.980 da, toplam verim 5.9 milyon ton ${ }^{-1}$, dekara ortalama verim ise $903 \mathrm{~kg} \mathrm{da}^{-1}$ olarak gerçekleșmiștir (TUIK, 2014). Ayrıca yeșil ve silaj olarak hayvan beslemede kullanılan bir kaba yem olarak 2014 yllında 4.015.913 da alanda ekilmiș, toplam silajlık verimi 18.6 milyon ton, dekara verim ise $4.630 \mathrm{~kg} \mathrm{da}^{-1}$ civarında gerçekleșmiștir (TUiK, 2014). Karadeniz, Ege, Akdeniz ve Güneydoğu Anadolu Bölgelerínde sulu șartlarda bașarı ile yetiștirilen silajlık mısır, Doğu Anadolu ve Marmara Bölgesi'nin bazı kesimlerinde de yetiștirilmektedir. Canlıların en önemli intiyacı barınmadan sonra beslenmedir. Toprak, bitkiler için besin kaynağı durumunda iken, bitkiler hem insanlar hem de hayvanlar için besin kaynağı durumundadır. Topraktan bitkiye, bitkiden insan ve hayvanlara besin maddelerinin kontrollü tașınımını içerisine alan toprak yönetimi ve gübreleme konusunda önemli çalıșmalar yapılmaktadır (Deliboran vd., 2016). Son yıllarda nitelikli gıda kavramının yaygıınlașması ile üzerinde en çok araștırma yapılan, insan ve hayvan beslenmesinde en önemli mikro besin elementlerinden biri de selenyumdur (Se). Uzun yıllar kanserojen bir element olarak tanınan, ancak 1957 yılında biyolojik sistemler için faydalı bir element olduğu ileri sürülen (Deliboran vd., 2018b) Se, hem insanlar hem de hayvanlar için zorunlu bir maddedir ve besin maddeleriyle birlikte yeterli miktarda alınması gerekmektedir (David vd., 1995; Surai, 2000; Deliboran, 2016; Deliboran vd., 2018b). Özellikle emiliminden sonra aminoasitlerin ve proteinlerin yapısına katılımı ile bitki beslemede oldukça önemlidir (Eriksson, 2001; Deliboran vd., 2018b). Bitkilerin Se alımı daha çok topraktan alım șeklinde gerçekleșmektedir fakat çok düșük oranda da olsa atmosferik yolla da Se alınabilmektedir. Se'nin topraktan emilebilmesi için mutlaka çözünür ve alınabilir bir formda olması gerekmektedir (Deliboran vd., 2018b), ve bitkiler için bu durum daha çok oksitlenmiș Selenat (Se+6) formunda olmaktadır. Selenyum topraklarda çoğunlukla selenat $\left(\mathrm{SeO}_{4}\right.$ $\left.{ }^{2}\right)$, selenit $\left(\mathrm{SeO}_{3}^{-2}\right)$ ve selenid $\left(\mathrm{Se}^{-2}\right)$ formlarında bulunmaktadır (Mikkelsen vd., 1990; Marchner, 1995; Çakmak vd., 2009). Selenyumun kuraklik ve düșük sıcaklık gibi çevresel stres etmenlerine karșı dayannıklııkta önemli bir role sahip olduğu, toksik $\mathrm{O}_{2}$ türevlerinden biri olan hidrojen peroksit $\left(\mathrm{H}_{2} \mathrm{O}_{2}\right)$ detoksifikasyonunu sağlayan glutatiyon peroksidaz enzimi için gerekli olduğu, bu enzimin aktivitesinin yüksek düzeyde kalmasını sağlayarak bitkileri düșük sıcaklık, yüksek ıșık intensitesi ve UV ıșık stresinden koruduğu (Xue ve Hartıkaınen, 2000; Seppanen vd., 2003; Çakmak vd., 2009), bitkilerin Se' yi fonksiyonel olarak bünyelerinde biriktirdiği fakat esas olarak tohumlarında daha çok 
biriktirdiği (Steven, 1994; Deliboran vd., 2018b) ileri sürülmektedir. Se uygulamaları bitkilerde, örneğin buğdayda (Çakmak vd., 2009) ve mısırda (Chilimbia vd., 2012; Deliboran vd., 2018a) tane, silaj verimi ve diğer bitkisel özellikleri etkilememekte, tanenin Se konsantrasyonunu ise etkileyerek arttırmaktadır. Deliboran vd. (2018a)'ya göre sodyum selenit ve sodyum selenat uygulamaları tane misırda istatistiksel açıdan bitki boyu, koçan yüksekliği, koçan sayısı, tane /koçan oranı, dekara verim ve tanenin yağ içeriği değerlerini etkilememiștir. Topraktan yapılan selenit uygulamaları tanenin Se içeriğini istatistiki olarak etkilemezken, yapraktan uygulanan selenat ise tanenin Se içeriğini etkilemiștir ve gerçekleștirilen uygulamalar ile tanenin Se içeriği artmıștır. Araștırmacılara göre $15 \mathrm{~g}$ Se ha-1 uygulaması ile $96 \mu \mathrm{g} \mathrm{kg}^{-1}$ Se'nin tanede biriktiği, $25 \mathrm{~g}$ Se ha-1

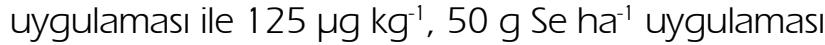
ile $214 \mathrm{\mu g} \mathrm{kg}^{-1}$, $75 \mathrm{~g} \mathrm{Se} \mathrm{ha}^{-1}$ uygulaması ile $420 \mu \mathrm{g}$ $\mathrm{kg}^{-1}$ ve $100 \mathrm{~g} \mathrm{Se} \mathrm{ha}^{-1}$ uygulaması ile $523 \mathrm{mg} \mathrm{kg}^{-1}$ Se birikiminin olduğu, Se düzeylerinin hem insan hem de hayvan beslenmesi için uygun düzeyde olduğu görülmektedir (Deliboran vd., 2018a; 2018b). Chilimbia vd. (2012) Se uygulamalarının silajlık mısırda verimi etkilemedeğini, çeșitlere göre verimin 4758-15792 kg ha-1 arasında değiștiğini, uygulamalar ile silaj Se içeriğinin arttığını ifade etmișlerdir. Wang vd. (2013) topraktan ve yapraktan $\mathrm{Na}_{2} \mathrm{SeO}_{3}$ formunda Se uygulamalarının tane ve silaj verimi ile diğer bitkisel özellikleri etkilemediğini, topraktan uygulamada sırasıyla 2009 yılında 5.41$9.13 \mathrm{t} \mathrm{ha}^{-1}, 2010$ yllinda ise 7.93-12.25 $\mathrm{t} \mathrm{ha}^{-1}$, yapraktan uygulamada sırasıyla 2009 yilında 6.15$9.91 \mathrm{t} \mathrm{ha}^{-1}, 2010$ yllında ise $9.58-17.05 \mathrm{t} \mathrm{ha}^{-1}$ verim aldıklarını bildirmektedir. Hidroponik sulama suyuna Se eklenmesi ile mısır bitkisinde (Longchamp vd., 2012) ve marulda (Duma vd., 2011) verimin artmadığı, $60 \mathrm{~g}$ Se ha-1 oranına kadar Se ile tohum muamelesinin üç çim çeșidinde de verimi etkilemediği (Cartes vd., 2011 ) görülmüș, buğdayda (Broadley vd., 2010), sarımsakta (Poldma vd., 2011 ) ve mısırda tane ve silaj (Chilimba vd., 2012a) veriminin artmadığı tespit edilmiștir. Ancak birkaç çalıșma Se uygulamasının bitkiyi olumlu etkilediğini göstermektedir. Saksıda yapılan bir çalıșmada, Se uygulamaları ile kontrol grubuna göre patates bitkisinden yüksek yumru verimi aldıkları, bununda Se'nin yașlanmayı geciktiren antioksidadif etkisiyle ilișkili olduğu belirtilmiștir (Turakaina, 2007). Benzer șekilde hidroponik denemelerde Se uygulamaları Brassica tohum üretiminde \% 43 oranında artıșa neden olmuștur ki bunun da yapraklarda ve çiçeklerdeki yüksek solunum aktivitesi ile ilgili olduğu ifade edilmiștir (Lyons vd., 2009). Hindibada yapılan bir denemede, Se uygulamaları genç hindibalarda solunum oranını arttırmıștır (Germ vd., 2007). Kuraklık stresi düzeyinin arttığı dönemde Se uygulamaları antioksidan aktivitesini, antioksidan düzeyini ve mısır tane verimi artırmıștır (Sajedi vd., 2011). Sonuç olarak bitkilerde Se uygulamaları antioksidan aktivitesinin ve solunum potansiyelinin artması nedeniyle pozitif etkili olabilmektedir. Bitkilerde birçok faktör Se etkinliğini arttırarak etkilemektedir. Bu faktörler toprak ve iklim koșullarının yanısıra Se uygulama zamanı, oranı, metodu, Se formu ve bitki türü olarak sıralanabilir (Rengel vd., 1999).

Bu çalıșma ile hayvan beslenmesinde kullanılan silajlık mısırda sodyum selenit $\left(\mathrm{Na}_{2} \mathrm{SeO}_{3}\right)$ ve sodyum selenat $\left(\mathrm{Na}_{2} \mathrm{SeO}_{4}\right)$ uygulamalarının yatma, bitki görünümü, kurtlu koçan sayısı, rastıkı bitki sayısı, koçan/bitki oranı, yaprak/sap oranı, bitki boyu gibi bitkisel özellikleri üzerine etkileri incelenmiștir.

\section{MATERYAL VE METOD}

\section{Araștırma lokasyonu}

Araștırma, 2013 ve 2014 yıllarında GAP Tarımsal Araștırma Enstitüsü'nün Talatdemirören Araștırma İstasyonu'nda Se noksanlığı görülen arazilerde yürütülmüștür. Șanlıurfa Güneydoğu Anadolu iklim bölgesine dahil olmakla birlikte, Akdeniz ikliminin etkisi altındadır. Yazları sıcak ve kurak, kıșları ise ılık olan bir iklim özelliği göstermektedir. Güneyden kuzeye ve batıdan doğuya gittikçe yağıș miktarı artmaktadır. Aylık ortalama sıcaklıklar temmuz ve ağustos aylarında $32{ }^{\circ} \mathrm{C}$ civarındadır. Günlük en yüksek sıcaklıklar ise aynı aylarda görülmektedir ve bu güne kadar kaydedilen günlük en yüksek sıcaklık temmuz ayında $46.8^{\circ} \mathrm{C}$ olarak ölçülmüștür. Günlük ortalama güneșlenme süresi yaz aylarında 12 saati geçmektedir. Șanlıurfa, Türkiye'de nispi nemin en düșük olduğu hat üzerindedir ve yaz aylarında nispi nem \% 35 civarındadır.

\section{Araștırmada kullanılan mısır çeșidi ve selenyum kaynakları}

Mısır çeșidi olarak bölgede yoğun olarak yetiștirilen DKC $955 F_{\text {1 }}$ silaj mısır çeșidi, selenyum kaynağı olarak ise sodyum selenit $\left(\mathrm{Na}_{2} \mathrm{SeO}_{3}\right)$ ve sodyum selenat $\left(\mathrm{Na}_{2} \mathrm{SeO}_{4}\right)$ kullanılmıștır. Katı halde bulunan sodyum selenit suda çözünebilme özelliğine sahiptir $\left(20^{\circ} \mathrm{C}\right.$ ta $\left.85 \mathrm{~g} / 100 \mathrm{gsu}\right)$, moleküler ağırlığı 172.9 g'dır. Sodyum selenitteki selenyum +4 oksidasyon durumundadır ve doğal olarak bulunur. 
Katı halde bulunan sodyum selenatın moleküler ağırlığı 188.94 g'dır. Bu molekül suda çözünebilme özelliğine sahiptir ( $20^{\circ} \mathrm{C}$ ta $83 \mathrm{~g} / 200 \mathrm{~g} \mathrm{su}$ ). Sodyum selenattaki Se en yüksek oksidasyon seviyesindedir (+6) ve bu özelliği nedeniyle de alkalin ve diğer oksitleyici șartlar altında stabil bir konumdadır. Sodyum selenat alkalin suda Se'un en sık görülen formudur (Sangbom vd., 2005).

\section{Deneme deseni}

Denemeler, 2013 ve 2014 yıllarında II. ürün tane mısır denemesi olacak șekilde tesadüf blokları deneme desenine göre 3 tekerrürlü olarak yürütülmüștür. Denemelerde 8 Se seviyesi (0-5-1015-25-50-75-100 g Se ha-1) kullanılmıștır. Selenit tohum ekiminden önce toprağa sıvı halde, selenat ise mısır bitkisi $50-70 \mathrm{~cm}$ boyuna geldiğinde yapraktan uygulanmıștır. Ekim ișlemi; sıra arası $70 \mathrm{~cm}$ ve sıra üzeri $16 \mathrm{~cm}$ olacak șekilde mibzer ile araștırmanın ilk yllında 24 Haziran 2013, ikinci yılında ise 17 Haziran 2014 tarihinde yapılmıștır. Araștırmanın her iki yllında deneme kurulacak arazide deneme öncesi alınan toprak örneğinin analiz sonuçları dikkate alınarak verilecek gübre miktarları belirlenmiștir. Analiz sonuçları Çizelge 1'de verilmiștir. Vejetasyon süresi boyunca mısıra verilecek gübre miktarları saf olarak $25 \mathrm{~kg} \mathrm{da}^{-1}$ azot (N) ve $10 \mathrm{~kg} \mathrm{da}^{-1}$ fosfora (P) tamamlanmıștır. Toprakta alınabilir potasyum (K) miktarı yeterli olduğundan K uygulanmamıștır. Son toprak ișleme uygulamasından önce P'nin tamamı ve N'nin bir kısmı taban gübresi olarak toprağa karıștırılarak verilmiștir. N'li gübrenin geri kalan kısmı ise üst gübre olarak mısır bitkileri $30-40 \mathrm{~cm}$ boylandığında banda verilmiștir. Ekimden hemen sonra çıkıș suyu verilmiștir. Diğer sulamalar, parsellere mümkün olduğunca eșit su verilecek șekilde karık usulü yapılmıștır. Yüzey akıșını engellemek için parseller arasına set yapılmıștır. Uygun zamanlarda çapa ve bir defa boğaz doldurma ișlemi yapılmıștır. Çıkıștan sonra gerektiğinde yabancı otlara karșı yabancı ot ilaçları kullanılmıș, ayrıca sap kurdu ve koçan kurdu vb. zararlılara karșı ilaçlı mücadele yapılmıștır. Denemenin yürütüldüğü her iki yılda, deneme öncesi denemenin kurulacağı arazideki su kaynağından su örneği alınarak analiz edilmiștir. Analiz sonuçları Çizelge 2'de verilmiștir.

\section{Bitkisel ölçümler}

Yatma (adet), her parselde fizyolojik olum döneminden sonra bitkinin dik durușuna göre 300'lik derecelik acıdan fazla yatan bitki sayısı sayılmıștır. Bitki görünümü (1-5), çeșide ait bitki formu homojen bir șekilde zayıf ya da kuvvetli görünüm olușturulmasına göre, 1-5 skalası ile değerlendirilmiștir. Çeșide ait bitkilerin görünümü kuvvetli ve sağlıkı bir yapı olușturmuș ise 1, zayıf, cilız ve deformasyonlu bir görünüm varsa 5'e kadar değer verilmiștir. Kurtlu koçan sayısı (adet) ve rastıklı bitki sayısı (adet parsel-1) hasattan önce ortadaki iki sırada tespit edilmiștir. Koçan/bitki oranı (\%), her parselden rastgele seçilen en az 5 bitkinin koçan ağırıkları ve bitki ağırlıkları tespit edilmiș ve oranlanmıștır. Yaprak/sap oranı (\%), her parselden rastgele seçilen en az 5 bitkinin (koçan hariç) yaprak ve sap ağılıkları tespit edilerek oranlanmıștır. Bitki boyu $(\mathrm{cm})$, döllenme sonrası toprak seviyesinden tepe püskülünün en uçtaki noktasına kadar olan mesafedir. Yeșil ot verimi $\left(\mathrm{kg} \mathrm{da}^{-1}\right)$, orta iki sıradan hasat edilen bitkilerin tartılması ile belirlenmiștir. Koçanda süt çizgisi $1 / 2-1 / 3$ durumunda olan bitkiler (\% 60-65 su) hasat edilmiștir. Biçim toprak seviyesinden $5-6 \mathrm{~cm}$ yükseklikten yapılmıștır. Elde

Çizelge 1. Araștırma yerine ait deneme öncesi toprağın bazı fiziksel ve kimyasal özelliklerinden bazıları

Table 1. Some of the physical and physical properties of the soil of the trial site

\begin{tabular}{lccccccccccccc}
\hline YIl & $\begin{array}{c}\mathrm{EC} \mathrm{ds} \\
\mathrm{m}^{-1}\end{array}$ & $\mathrm{pH}$ & $\begin{array}{c}\text { Kireç } \\
\%\end{array}$ & $\begin{array}{c}\mathrm{P}_{2} \mathrm{O}_{5} \\
\mathrm{kgda}^{-1}\end{array}$ & $\begin{array}{c}\mathrm{K} 2 \mathrm{O} \\
\mathrm{kgda}^{-1}\end{array}$ & $\begin{array}{c}\mathrm{N} \\
\%\end{array}$ & $\begin{array}{c}\mathrm{S} \\
\mathrm{ppm}\end{array}$ & $\begin{array}{c}\mathrm{Mg} \\
\mathrm{ppm}\end{array}$ & $\begin{array}{c}\mathrm{B} \\
\mathrm{ppm}\end{array}$ & $\begin{array}{c}\text { Se } \\
\mathrm{ppb}\end{array}$ & $\begin{array}{c}\text { Kum } \\
\%\end{array}$ & $\begin{array}{c}\text { Silt } \\
\%\end{array}$ & $\begin{array}{c}\text { Kil } \\
\%\end{array}$ \\
\hline 2013 & 0.98 & 7.9 & 31.2 & 7.6 & 138 & 0.06 & 18.5 & 1678 & 0.32 & 3.9 & 28.5 & 19.6 & 51.9 \\
2014 & 1.06 & 7.5 & 29.2 & 4.2 & 151 & 0.07 & 16.6 & 840 & 1.27 & 3.5 & 27.5 & 19.3 & 53.2 \\
\hline
\end{tabular}

Çizelge 2. Araștırmada kullanılan sulama suyunun analiz sonuçları

Table 2. Analysis results of irrigation water used in the study

\begin{tabular}{|c|c|c|c|c|c|c|c|c|c|c|c|c|c|c|}
\hline \multirow[b]{2}{*}{ Ylllar } & \multicolumn{5}{|c|}{ Katyonlar (me L-1) } & \multicolumn{5}{|c|}{ Anyonlar (me L-1) } & \multirow[b]{2}{*}{$\mathrm{pH}$} & \multirow[b]{2}{*}{ SAR } & \multirow[b]{2}{*}{ B } & \multirow[b]{2}{*}{ Sinif } \\
\hline & $\begin{array}{c}\text { EC } \\
\mu \mathrm{Sm}^{-1}\end{array}$ & $\mathrm{Na}$ & $\mathrm{K}$ & $\begin{array}{c}\mathrm{Ca}+ \\
\mathrm{Mg}\end{array}$ & $\begin{array}{l}\text { Top. } \\
\text { katyon }\end{array}$ & $\mathrm{CO}_{3}$ & $\mathrm{HCO}_{3}$ & $\mathrm{Cl}$ & $\mathrm{SO}_{4}$ & $\begin{array}{l}\text { Top. } \\
\text { Anyon }\end{array}$ & & & & \\
\hline 2013 & 354 & 0.08 & 0.02 & 3.2 & 3.3 & - & 1.9 & 1.1 & 0.3 & 3.3 & 7.45 & 0.06 & - & $T_{2} A_{1}$ \\
\hline 2014 & 356 & 0.8 & 0.02 & 3.3 & 3.4 & - & 2.8 & 1.2 & 0.4 & 3.3 & 7.49 & 0.06 & - & $\mathrm{T}_{2} \mathrm{~A}_{1}$ \\
\hline
\end{tabular}


edilen veriler birim alan verimine çevrilmiștir (t ha-1) Kuru madde verimi ( $\left.\mathrm{kg} \mathrm{da}^{-1}\right)$, biçimden sonra her parselden yeșil ot için hasat edilen parseli temsil eden 1 bitki rastgele alınıp parçalanmıș (1-2 cm) ve kurutma dolabında 48 saat 105 ${ }^{\circ} C^{\prime}$ de kurutulmuștur. Örnek daha sonra 24 saat desikatörde bekletilip tartılarak, kuru madde oranı belirlenmiștir. Elde edilen kuru madde değeri yeșil ot verimi ile çarpılarak birim alan kuru madde verimine çevrilmiștir. Kuru madde (\% KM), yaș ve kuru ot değerlerinden orantı yolu ile belirlenmiștir.

\section{Kimyasal analizler}

Toprak örneklerinde, tekstür hidrometre yöntemi ile (Bouyoucos, 1955); pH 1:2,5 toprak:su karıșımında, elektriksel iletkenlik (EC) saturasyon çamurunda, kireç $\left(\mathrm{CaCO}_{3}\right)$ Scheibler kalsimetresi ile (Tüzüner, 1990); organik madde (OM) modifiye Walkley-Black yöntemiyle (Black, 1965); toplam N modifiye Kjeldahlyöntemiyle, değișebilir K, kalsiyum (Ca) ve magnezyum (Mg) ve sodyum (Na) $1 \mathrm{~N}$ amonyum asetat $(\mathrm{pH}=7)$ ekstraksiyonu ile (Kacar, 1995); alınabilir $\mathrm{P} \mathrm{NaHCO}_{3}$ ekstraksiyonu ile (Olsen ve Sommers, 1982); alınabilir demir (Fe), çinko (Zn), mangan (Mn) ve bakır (Cu) DTPA-TEA (Diethylene tetramine penta acetic acid-Triethanolamine) ekstraksiyonu ile (Lindsay ve Norvell, 1978), alınabilir B ise topraktan sıcak su ile ekstrakte edilen B miktarının azometin-H ile olușturulan kompleksin renk yoğunluğuna dayanılarak (Kacar, 1995), alınabilir Se ise $\mathrm{KH}_{2} \mathrm{PO}_{4}$ ektraksiyon yöntemi ile elde edilen süzüğün (Çakmak vd., 2009) ETC60 (Elektro Termal Temperature Controller) ve VGA-77 (Vapor Generator Aparatus) aparatlarının bağlandığı Atomik Absorbsiyon Spectrofotometre cihazı (ASS) ile okunması sonucu belirlenmiștir.

\section{İstatistik analizler}

Denemelerden elde edilen veriler her yıl varyans analizi ile değerlendirilmiș, homojenlik testleri yapılmıș, homojen varyanslarda birleșik varyans analizi uygulanmıștır, yı $X$ konu interaksiyonu önemli çıktığında yıllar ayrı ayrı değerlendirilmiștir, deneme konuları arasındaki farklııklar ise LSD testleri ile kontrol edilmiștir.

\section{BULGULAR VE TARTIȘMA}

Selenyum uygulamalarının yatma, bitki görünümü, kurtlu koçan ve rastıklı bitki sayısı üzerine etkileri

Kontrol grubuna göre kıyaslama yapıldığında, uygulamalarının yatma, bitki görünümü, kurtlu koçan ve rastıklı bitki sayısı üzerine herhangi bir etkisi gözlenmemiștir (Çizelge 3). Deliboran vd. (2018a)

Çizelge 3. Selenyum uygulamalarının yatma, bitki görünümü, kurtlu koçan sayısı ve rastıkı bitki sayısı üzerine etkileri Table 3. The effects of selenium applications on odging, plant appearance, worm maize ear number and smut plant number

\begin{tabular}{|c|c|c|c|c|c|c|c|c|c|}
\hline \multirow{2}{*}{$\begin{array}{l}\text { Selenyum } \\
\text { kaynağı }\end{array}$} & \multirow{2}{*}{$\begin{array}{l}\text { Uygulama } \\
\text { seviyeleri }\end{array}$} & \multicolumn{2}{|c|}{$\begin{array}{c}\text { Yatma } \\
\left(\text { adet parsel }{ }^{-1}\right)\end{array}$} & \multicolumn{2}{|c|}{$\begin{array}{l}\text { Bitki görünümü } \\
\text { (1-5 skalası) }\end{array}$} & \multicolumn{2}{|c|}{$\begin{array}{l}\text { Kurtlu koçan sayısı } \\
\text { (adet parcel }^{-1}\end{array}$} & \multicolumn{2}{|c|}{$\begin{array}{c}\text { Rastıklı bitki sayısı } \\
\text { adet parcel }{ }^{-1} \text { | }\end{array}$} \\
\hline & & 2013 & 2014 & 2013 & 2014 & 2013 & 2014 & 2013 & 2014 \\
\hline \multirow{8}{*}{ Sodium selenit } & $0 \mathrm{~g} \mathrm{ha}^{-1}$ & 0 & 0 & 2 & 2 & 0 & 0 & 0 & 0 \\
\hline & $5 \mathrm{~g} \mathrm{ha}^{-1}$ & 0 & 0 & 1 & 2 & 0 & 0 & 0 & 1 \\
\hline & $10 \mathrm{~g} \mathrm{ha}^{-1}$ & 0 & 0 & 2 & 2 & 0 & 0 & 0 & 1 \\
\hline & $15 \mathrm{~g} \mathrm{ha}^{-1}$ & 0 & 0 & 2 & 2 & 0 & 0 & 0 & 1 \\
\hline & $25 \mathrm{~g} \mathrm{ha}^{-1}$ & 0 & 0 & 1 & 1 & 0 & 0 & 0 & 0 \\
\hline & $50 \mathrm{~g} \mathrm{ha}^{-1}$ & 0 & 0 & 2 & 2 & 0 & 0 & 0 & 0 \\
\hline & $75 \mathrm{~g} \mathrm{ha}^{-1}$ & 0 & 0 & 1 & 1 & 0 & 0 & 0 & 1 \\
\hline & $100 \mathrm{~g} \mathrm{ha}^{-1}$ & 0 & 0 & 1 & 1 & 0 & 0 & 0 & 0 \\
\hline \multirow{8}{*}{ Sodium selenat } & $0 \mathrm{~g} \mathrm{ha}^{-1}$ & 0 & 0 & 1 & 2 & 0 & 0 & 0 & 0 \\
\hline & $5 \mathrm{~g} \mathrm{ha}^{-1}$ & 0 & 0 & 2 & 2 & 0 & 0 & 0 & 1 \\
\hline & $10 \mathrm{~g} \mathrm{ha}^{-1}$ & 0 & 0 & 2 & 1 & 0 & 0 & 0 & 1 \\
\hline & $15 \mathrm{~g} \mathrm{ha}^{-1}$ & 0 & 0 & 2 & 2 & 0 & 0 & 0 & 1 \\
\hline & $25 \mathrm{~g} \mathrm{ha}^{-1}$ & 0 & 0 & 2 & 2 & 0 & 0 & 0 & 0 \\
\hline & $50 \mathrm{~g} \mathrm{ha}^{-1}$ & 0 & 0 & 1 & 2 & 0 & 0 & 0 & 0 \\
\hline & $75 \mathrm{~g} \mathrm{ha}^{-1}$ & 0 & 0 & 2 & 2 & 0 & 0 & 0 & 1 \\
\hline & $100 \mathrm{~g} \mathrm{ha}^{-1}$ & 0 & 0 & 1 & 2 & 0 & 0 & 0 & 0 \\
\hline
\end{tabular}


sodyum selenit ve sodyum selenat uygulamalarının tane mısırda yatma, bitki görünümü, koçan ucu kapalılığı, koçan görünümü ve rastıklı bitki sayısı üzerine herhangi bir etkisinin olmadığını ifade etmektedir. Çalıșmadan elde edilen sonuçlar araștırmacıların sonuçları ile uyum içerisindedir.

\section{Selenyum uygulamalarının bitki boyu üzerine etkileri}

Selenit uygulamalarında bitki boyu değerleri açısından varyansların homojen olmadığı görülmüș ve birleșik varyans analizi uygulanmamıștır. Yıllar ayrı ayrı değerlendirildiğinde 2013 yılında bitki boyları 224-246 cm, 2014 yılında ise 231-240 cm arasında, en yüksek boy 2013 yılında $246 \mathrm{~cm}$ ile $15 \mathrm{~g} \mathrm{Se} \mathrm{ha-1}, 2014$ yllında ise $240 \mathrm{~cm} 50 \mathrm{~g} \mathrm{Se}$ ha $^{-1}$ uygulamasından elde edilmiștir, uygulamalar istatistiksel açıdan bitki boyu değerlerini etkilememiștir. Selenat uygulamalarında varyansların homojen olduğu görülmüș birleșik varyans analizi uygulanmıștır. Yıllar toplu olarak değerlendirildiğinde konular arasında istatistiki olarak fark olușmazken bitki boyları 236-239 cm arasında değișmiștir. En yüksek bitki boyu 239 cm ile $50 \mathrm{~g} \mathrm{Se} \mathrm{ha}^{-1}$ ve $100 \mathrm{~g} \mathrm{Se} \mathrm{ha}^{-1}$ uygulamalarından elde edilmiș, uygulamalar istatistiksel açıdan bitki boyu değerlerini etkilememiștir. Deliboran vd. (2018a) Șanlıurfa koșullarında yürüttükleri çalıșmada, sodyum selenit ve sodyum selenat uygulamalarının tane mısır bitki boyu değerlerinin etkilemediğini, sırasıyla bitki boyu değerinin 2013 yllında $218-230 \mathrm{~cm}$ ve 23-233, 2014 yllında ise 244 $249 \mathrm{~cm}$ ve $244-251 \mathrm{~cm}$ arasında değiștiğini ifade etmektedir. Van koșullarında yapılan bir çalıșmada bitki boyu değerlerinin 143.7-242.6 cm (Akdeniz vd., 2004); diğer birkaç çalıșmada ise Samsun ili Çarșamba koșullarında 276-332 cm (Öner vd., 2011 ); Tokat koșullarında 177.4-292.4cm (İptaș vd., 2002a) arasında değiștiği bildirilmektedir. Çalıșmadan elde edilen bitki boyu değerleri her iki uygulama için araștırmacıların sonuçları ile uyum içerisindedir.

\section{Selenyum uygulamalarının koçan/bitki oranı üzerine etkileri}

Koçan/bitki oranı açısından selenit uygulamalarında yıllar toplu olarak değerlendirildiğinde konular arasında istatistiki olarak 0.05 önem düzeyinde fark olușmuștur. Ancak yıl X konu interaksiyonu önemli çıktığından yıllar ayrı ayrı değerlendirilmiștir. Koçan/bitki oranı 2013 yılında \% 43-52, 2014 yilında \% 42-46 arasında değișmiștir. 2013 yılında konular arasında istatistiki yönden fark olușmuș, en yüksek değerler 2013 yllında \% 52 ile $5 \mathrm{~g} \mathrm{Se} \mathrm{ha-1}$ uygulamasından, 2014 yllında ise \% 46 ile $10 \mathrm{~g} \mathrm{Se} \mathrm{ha-1}, 15 \mathrm{~g} \mathrm{Se} \mathrm{ha}^{-1}$

Çizelge 4. Selenyum uygulamalarının bitki boyu, koçan yüksekliği, koçan sayısı ve tane/koçan oranı üzerine etkileri Table 4. Effects of selenium applications on plant height, ear size, ear number and grain / ear ratio

\begin{tabular}{|c|c|c|c|c|c|c|c|c|c|c|}
\hline \multirow{2}{*}{$\begin{array}{l}\text { Selenyum } \\
\text { kaynağı }\end{array}$} & \multirow{2}{*}{$\begin{array}{c}\text { Uygulama } \\
\text { seviyeleri }\end{array}$} & \multicolumn{3}{|c|}{ Bitki boyu (cm) } & \multicolumn{3}{|c|}{ Koçan/bitki oranı (cm) } & \multicolumn{3}{|c|}{ Yaprak/sap oranı (\%) } \\
\hline & & 2013 & 2014 & ORT & 2013 & 2014 & ORT & 2013 & 2014 & ORT \\
\hline \multirow{8}{*}{$\begin{array}{l}\text { Sodium } \\
\text { selenit }\end{array}$} & $0 \mathrm{~g} \mathrm{ha}^{-1}$ & 243 & 235 & 239 & $44 \mathrm{~cd}$ & 43 & 44 & $34 d$ & 44 & 39 \\
\hline & $5 \mathrm{~g} \mathrm{ha}^{-1}$ & 224 & 231 & 228 & 52 а & 44 & 48 & $44 \mathrm{ab}$ & 42 & 43 \\
\hline & $10 \mathrm{~g} \mathrm{ha}^{-1}$ & 240 & 232 & 236 & $43 d$ & 46 & 45 & 45 a & 41 & 43 \\
\hline & $15 \mathrm{~g} \mathrm{ha}^{-1}$ & 246 & 235 & 241 & $44 \mathrm{~cd}$ & 46 & 45 & 47 a & 41 & 44 \\
\hline & $25 \mathrm{~g} \mathrm{ha}^{-1}$ & 238 & 238 & 238 & $45 \mathrm{~cd}$ & 43 & 44 & $36 \mathrm{~cd}$ & 39 & 38 \\
\hline & $50 \mathrm{~g} \mathrm{ha}^{-1}$ & 235 & 240 & 238 & 51 ab & 46 & 49 & $43 \mathrm{ab}$ & 41 & 42 \\
\hline & $75 \mathrm{~g} \mathrm{ha}^{-1}$ & 229 & 236 & 233 & $46 \mathrm{~cd}$ & 45 & 46 & $39 \mathrm{bc}$ & 40 & 40 \\
\hline & $100 \mathrm{~g} \mathrm{ha}^{-1}$ & 233 & 235 & 234 & $48 \mathrm{bc}$ & 42 & 45 & $40 \mathrm{bc}$ & 43 & 42 \\
\hline \multirow{8}{*}{$\begin{array}{l}\text { Sodium } \\
\text { selenat }\end{array}$} & $0 \mathrm{~g} \mathrm{ha}^{-1}$ & 243 & 232 & 238 & 44 & 43 & 44 & $39.39 \mathrm{bcd}$ & 36 & $37 \mathrm{CD}$ \\
\hline & $5 \mathrm{~g} \mathrm{ha-}^{1}$ & 240 & 231 & 236 & 43 & 44 & 43 & $33.34 \mathrm{e}$ & 36 & $35 \mathrm{D}$ \\
\hline & $10 \mathrm{~g} \mathrm{ha}^{-1}$ & 241 & 231 & 236 & 42 & 45 & 43 & 37.73 cde & 40 & $39 \mathrm{BC}$ \\
\hline & $15 \mathrm{~g} \mathrm{ha}^{-1}$ & 244 & 232 & 238 & 46 & 45 & 46 & $35.30 \mathrm{de}$ & 40 & 38 CD \\
\hline & $25 \mathrm{~g} \mathrm{ha}^{-1}$ & 239 & 237 & 238 & 38 & 45 & 42 & $39.47 \mathrm{bcd}$ & 42 & $41 \mathrm{ABC}$ \\
\hline & $50 \mathrm{~g} \mathrm{ha}^{-1}$ & 237 & 241 & 239 & 46 & 46 & 46 & 42.86 abc & 42 & $42 \mathrm{AB}$ \\
\hline & $75 \mathrm{~g} \mathrm{ha}^{-1}$ & 234 & 242 & 238 & 47 & 45 & 46 & 43.48 ab & 41 & $42 \mathrm{AB}$ \\
\hline & $100 \mathrm{~g} \mathrm{ha}^{-1}$ & 239 & 240 & 239 & 40 & 42 & 41 & 45.67 a & 39 & $43 \mathrm{~A}$ \\
\hline
\end{tabular}


ve $50 \mathrm{~g} \mathrm{Se} \mathrm{ha-1}$ uygulamalarından elde edilmiștir. Selenat uygulamalarında yıllar toplu olarak değerlendirildiğinde konular arasında istatistiki olarak fark olușmazken koçan/bitki oranı \% 41-46 arasında değișmiștir. En yüksek koçan/bitki oranı \% 46 ile $75 \mathrm{~g}$ Se ha-1 uygulamasından elde edilmiștir (Çizelge 4). Akdeniz vd. (2004) Van koșullarında koçan/bitki oranı \% 38.20-49.00; Özata vd. (2012) Samsun ili Çarșamba'da \% 30-48; Öner vd. (2011) Samsun-Çarșamba lokasyonunda \% 33-41; İptaș vd. (2002a) ise Tokat ekolojik koșullarında \% 32.9-42.0 arasında değiștiğini ifade etmișlerdir. Çalıșmadan elde edilen koçan/bitki oranı değerleri her iki uygulama için araștırmacıların sonuçları ile uyum içerisindedir.

\section{Selenyum uygulamalarının yaprak/sap oranı üzerine etkileri}

Selenit uygulamalarında yaprak/sap oranı bakımındanyıllar toplu olarak değerlendirildiğinde konular arasında istatistiki olarak 0.05 önem düzeyinde fark olușmuștur. Ancak yıl $X$ konu interaksiyonu önemli çıktığından yıllar ayrı ayrı değerlendirilmiștir. Yaprak/sap oranı değerleri 2013 yılında \% 34-47, 2014 yılında \% 3944 arasında değișmiștir. 2013 yılında konular arasında istatistiki yönden fark olușmuș, en yüksek değerler 2013 yılında sırasıyla \% 45 ve \% 47 ile $10 \mathrm{~g} \mathrm{Se} \mathrm{ha}^{-1}$ ve $15 \mathrm{~g} \mathrm{Se} \mathrm{ha-1}$ uygulamasından elde edilirken, 2014 yılında \% 44 ile $0 \mathrm{~g}$ Se ha $^{-1}$ uygulamasından elde edilmiștir. Selenat uygulamalarında ise konular arasında istatistiki olarak 0.01 önem düzeyinde fark olușmuș ve yaprak/sap oranı \% 34.65-42.54 arasında değișmiștir. En yüksek değer ise \% 43 ile $100 \mathrm{~g}$ Se ha' ${ }^{-1}$ uygulamasından elde edilmiștir (Çizelge 4). Yaprak/sap oranının Van koșullarında yapılan çalıșmada \% 17.30-23.50 (Akdeniz vd., 2004); Samsun ili Çarșamba'da \%14-22 (Özata vd., 2012 ) ve \% 26-43 (Öner vd., 2011 ); Tokat ekolojik koșullarında ise \% 15.3-21.2 (İptaș vd., 2002a) arasında değiștiği bildirilmektedir. Çalıșmadan elde edilen yaprak/sap oranı değerleri Öner vd. (2011) ile uyumlu iken, Yılmaz (1999); Akdeniz vd. (2004); Özata vd. (2012) ve İptaș vd. (2002a)'dan yüksek bulunmuștur. Bu farklıı̆ın çeșit özelliği ve bakım șartlarından kaynaklanabileceği düșünülmektedir. Bitki gelișiminde selenyumun etkisi bitki türüne ve çeșidine bağlı olduğu bazı çalıșmalarda ileri sürülmektedir. Örneğin Monivip hindiba çeșidinde toplam kuru madde oranının Se uygulanan bitkilerde kontrol grubuna göre yüksek olduğu, ancak aynı çeșitte iki grup arasında bitki gelișimi açısından herhangi bir fark gözlenmediği, selenyum uygulamaları 43 ng Se g $^{-1}$ KM - 46 ng $\left.\mathrm{Se}^{-1} \mathrm{KM}\right)$ ile hindiba bașlarındaki Se içeriği kontrol grubuna (21 ng Se $g^{-1}$ KM - 24 ng Se $\left.g^{-1} K M\right)$ göre iki kat fazla çıktığı bildirilmektedir (Germ ve ark., 2007). Benzer șekilde düșük dozda selenat uygulamasının (1 mg Se kg-1) GF677 Prunus anacında bitki gelișimini teșvik ederken MR.S.2/5 anacının biyokütlesinde herhangi bir değișiklik gözlenmediği ifade edilmektedir (Pezzarossa vd., 2009). Selenyum uygulamalarının bitkilerde, örneğin buğdayda (Çakmak vd., 2009; Duscay vd., 2007) ve misırda (Chilimbia vd., 2012) tane ve silaj verimi ile diğer bitkisel özellikleri etkilemediği, tanenin Se konsantrasyonunu ise etkileyerek arttırdığı bilinmektedir. Bu fikir farklı bitki türlerinde birçok çalıșma ile literatürde desteklenmiștir (Broadley vd., 2010; Duma vd., 2011; Cartes vd., 2011; Poldma vd., 2011; Chilimba vd., 2012a Longchamp vd., 2013; Deliboran vd., 2018a; 2018b; Deliboran, 2020). Deliboran vd. (2018a) tane misırda selenyum uygulamalarının istatistiksel açıdan bitki boyu, koçan yüksekliği, koçan sayısı, tane/koçan oranı, 1000 dane ağırlığı gibi bitkisel özellikleri etkilemediğini belirtmektedir.

Se uygulamasının bitkiyi olumlu etkilediği birkaç tane çalıșmasından biri olan ve saksıda yürütülen çalıșmada, Se uygulamaları ile kontrol grubuna göre patates bitkisinden yüksek yumru verimi alındığı, bunun da Se'nin yașlanmayı geçiktiren antioksidadif etkisiyle ilișkili olduğu belirtilmiștir (Turakainen, 2007). Hidroponik denemelerde Se uygulamalarının Brassica tohum üretiminde \% 43 oranında artıșa neden olduğu, bunun da yapraklarda ve çiçeklerdeki yüksek solunum aktivitesi ile ilgili olduğu ifade edilmiștir (Lyons vd., 2009). Se uygulamalarının genç hindibalarda solunum oranını (Germ vd., 2007), mısırda ise kuraklık stresi düzeyinin arttığı dönemde antioksidan aktivitesini, antioksidan düzeyini ve tane verimi arttırdığı bildirilmiștir (Sajedi vd., 2011 ). Sonuç olarak bitkilerde Se uygulamalarının antioksidan aktivitesinin ve solunum potansiyelinin artması nedeniyle pozitif etkili olabildiği (Rengel vd., 1999)., birçok faktörün Se etkinliğini arttırarak etkilediği, özellikle toprak ve iklim koșullarının dıșında uygulama zamanı, oranı, metodu, Se formu ve bitki türünün etkili olduğu düșünülmektedir (Deliboran vd., 2018b). 
Se uygulamalarının bitkilerde verim ile diğer bitkisel özellikleri etkilemediği, tanenin Se konsantrasyonunu ise etkileyerek arttırdığı bilinmektedir. Chilimbia vd. (2012) çeșitlere göre tane mısır veriminin 2764-7009 kg ha-1, silaj mısır veriminin de 4758-15792 kgha-1 arasında değiștiğini, Se uygulamaları ile tane ve silaj Se içeriğinin arttığını ifade etmișlerdir. Deliboran vd. (2018a; 2018b) topraktan uygulanan sodyum selenit ile yapraktan uygulanan sodyum selenat uygulamalarının tane mısırda tane verimini ve biomas özelliklerini etkilemediğini, selenit uygulamalarında verim ve biomas değerlerinin sırasıyla 9.10-9.52 $\mathrm{t} \mathrm{ha}^{-1}$ ve 7.87-8.34 $\mathrm{t} \mathrm{ha}^{-1}$, selenat uygulamalarında ise 8.288.99 t ha-1 ve 8.01-8.50 t ha-1 arasında değiștiğini, Se uygulamaları ile tanenin Se içeriğinin arttığını bildirmektedir. Wang vd. (2013) topraktan ve yapraktan $\mathrm{Na}_{2} \mathrm{SeO}_{3}$ formunda Se uygulamalarının mısır tane ve silaj verimini etkilemediğini, topraktan uygulamada sırasıyla 2009 yılında 5.41-9.13 t ha 1, 2010 yılında ise 7.93-12.25 t ha-1, yapraktan uygulamada sırasıyla 2009 yılında 6.15-9.91 t ha-1, 2010 yılında ise 9.58-17.05 t ha-1 verim aldıklarını bildirmektedir. Hidroponik sulama suyuna Se eklenmesi ile mısır bitkisinde (Longchamp vd. 2013) ve marulda (Duma vd., 2011 ) verimin artmadığı, 60 $\mathrm{g}$ Se ha-1 oranına kadar Se ile tohum muamelesinin üç çim çeșidinde de verimi etkilemediği (Cartes vd., 2011 ) görülmüș, buğdayda (Broadley vd., 2010), sarımsakta (Poldma vd., 2011 ) ve misırda tane ve silaj (Chilimba vd., 2012a) veriminin artmadığı tespit edilmiștir.

\section{SONUC̣LAR}

Silajlık misırda topraktan uygulanan sodyum selenit ile yapraktan uygulanan sodyum selenat uygulamalarının bitkisel özellikler üzerine etkileri irdelenecek olursa; kontrol grubuna göre kıyaslama yapıldığında uygulamalarının silajlık mısırda yatma, bitki görünümü, kurtlu koçan sayısı ve rastıklı bitki sayısı üzerine herhangi bir etkisi gözlenmemiștir. Selenit uygulamaları istatistiksel açıdan koçan/bitki oranı ile yaprak/sap oranı değerlerini etkilemiștir ve yıl X konu interaksiyonu önemli çıkmıștır. Her iki uygulamada 2013 yılında konular arasında istatistiki yönden fark olușmuș, en yüksek değerler sırasıyla \% 52 ile $5 \mathrm{~g} \mathrm{Se} \mathrm{ha-1}$ uygulaması ile \% 45 ve \% 47 ile $10 \mathrm{~g} \mathrm{Se} \mathrm{ha-1}^{-1}$ ve $25 \mathrm{~g} \mathrm{Se} \mathrm{ha-1}$ uygulamalarından elde edilmiștir. Selenat uygulamaları koçan/bitki oranı değerleri istatistiksel olarak etkilemezken yaprak/sap oranlarını etkilemiș, en yüksek değerler \% 43 ile
$100 \mathrm{~g} \mathrm{Se} \mathrm{ha-1}$ uygulamalarından elde edilmiștir. Selenyum uygulamaları bitki boyu değerlerini etkilememiștir. Topraktan uygulanan sodyum selenit ile yapraktan uygulanan sodyum selenat uygulamalarınınsilajlıkmısırın bazı bitkiselözellikleri üzerine etkisinin belirlenmesi amacıyla yapılan bu çalıșma sonucunda; Selenyum uygulamalarının birçok bitkisel özelliği etkilemediği, uygulamaların sadece koçan/bitki oranı ile yaprak/sap oranı gibi bazı bitkisel özellikleri etkilediği görülmektedir. Selenyum uygulamalarının genel olarak mısır bitkisinin bitkisel özelliklerini etkilemediği, uygulamaların mısır hasılının Se içeriği ve yem kalitesi açısından etkili olabileceği yapılan çalıșmalarda ileri sürmektedir. Ancak bitkilerde Se uygulamalarının pozitif etkili olabileceği, birçok faktörün Se etkinliğini arttırarak etkilediği, özellikle toprak ve iklim koșullarının dıșında uygulama zamanı, oranı, metodu, Se formu ve bitki türünün etkili olabileceği düșünülmektedir.

\section{KAYNAKLAR}

Açıkgöz E (1991). Yem bitkileri. Uludağ Üniv. Ziraat Fakültesi Yayın No: 7-025-0210, Bursa.

Açıkgöz E (2001). Yem bitkileri (3.Baskı). Uludağ Üniversitesi Güçlendirme Vakfı Yayın No: 182, Bursa.

Alçiçek A, Karaayvaz BK (2003). 2002 yılı çiftçi koșullarında silo yemi yapımında yarșanılan sorunlar ve çözüm önerileri. TAYEK/TYUAP Toplantısı Bildirileri, Ege Tarımsal Araștırma Enstitüsü Müdürlüğü Yayınları, No: 106, 136-146.

Ak I, Doğan R (1997). Bursa bölgesinde yetiștirilen bazı mısır çeșitlerinin verim özellikleri ve silaj kalitelerinin belirlenmesi. Türkiye I.Silaj Kongresi, 16-10 Eylül, Bursa, s. 8392.

Akdeniz H, Yılmaz I, Andiç N, Zorer Ș (2004). Bazı mısır çeșitlerinde verim ve yem değerleri üzerine bir araștırma. Yüzüncü Yıl Üniversitesi, Ziraat Fakültesi, Tarım Bilimleri Dergisi, J. Agric Sci., 14(1): 47-51.

Black CA (1965). Methods of soil analiysis, Part 2. American Society of Agronomy Inc., Publisher Madison, Wilconsin, USA, pp. 1372-1376.

Bouyoucos GJ (1951). Arecelibration of the hydrometer for marking mechanical analysis of soil. Argon Journal, 43: 433-437

Broadley MR, Alcock J, Alford J, Cartwright P, Foot I, Fairweather-Tait SJ, Hart DJ, Hurst R, Knott P, McGrath SP, Meacham MC, Norman K, Mowat H, Scott P, Stroud JL, Tovey M, Tucker M, White PJ, Young SD, Zhao FJ (2010). Selenium biofortification of high-yielding winter wheat (Triticum aestivum L.) by liquid or granular Se fertilisation. Plant Soil, 332: 5-18.

Chilimba ADC, Young SD, Black CR, Meacham MC, Lammel J, Broadley MR (2012). Agronomic biofortification of maize with selenium (Se) in Malawi. Field Crop Research. 125: 118-128 
Chilimba ADC, Young SD, Black CR, Meacham MC, Lammel J, Broadley MR (2012a). Agronomic biofortification of maize with selenium (Se) in Malawi. Field Crop, 125: 118128.

Cartes P, Gianfreda L, Mora ML (2005). Uptake of selenium and its antioxidant activity in ryegrass when applied as selenite and selenite forms. Plant Soil, 276: 359-367.

Cakmak I, Öztürk L, Bașağa H, Cekiç C, Taner S, Irmak S, Geren H, Kılıç H, Aydın N, Avcı M, Gezgin S (2009). Türkiye'de seçilmiș blgelerde bugdayların ve toprakların selenyum konsantrasyonunun araștırılması, selenyum gübrelemesine buğdayın reaksiyonu ve selenyumca zengin genotiplerin fizyolojik olarak karakterizasyonu. Proje Nno: 1050637. Tübitak Sonuç Raporu.

David JG (1995). Diagnosing Selenium Toxicity, Colorado State University Cooperative Extension.

Deliboran A (2016). Selenyum, bitki, hayvan ve insan sağığı. Bilinçli Yașam Dergisi, Ocak 2016, Sayı: 12 ISSN 2149 $147 X$.

Deliboran A (2020). The effects of sodium selenate application on yield, field quality and selenium content of silage maize. Bulgarian Journal of Agricultural Science, Agricultural Academy (in press on 6/2020).

Deliboran A, Ișık Y, Aslan H, Nacar AS, Kara H, Tekgül YT, Harmankaya M, Gezgin S (2018a). Selenyum uygulamalarının tane mısırda verim parametreleri ile tanenin selenyum, protein ve yağ içeriği üzerine etkileri. Toprak İlimi ve Bitki Besleme Dergisi, Soil Science Society of Turkey, ISSN 2146-8141, 6(1): $1-11$.

Deliboran A, Ișık Y, Aslan H, Nacar AS, Kara H, Tekgül YT, Harmankaya M, Gezgin S (2018b). Effect of selenium application method on selenium and macro-micro nutrient content of grain maize in Turkey. YYU J AGR SCI, ISSN: 13087576, e-ISSN: 1308-7584, 2018 (28): 294-306.

Duma M, Alsin, I, Dubova L, Stroksa L, Smiltina Z (2011). The effect of sodium selenite and selenite on the quality of lettuce. In: Conference proceedings of the 6th Baltic Conference on Food Science and Technology Foodbalt, Jelgava, Latvia.

Duscay L, Lozek O, Varga L (2009). The influence of selenium soil application on its content in spring wheat, Plant Soll Environ., 55(2): 80-84.

Eriksson J (2001). Concentrations of 61 trace elements in sewage sludge, farmyard manure, mineral fertilizer, recipitation and in oil and crops. Report 5159, The Swedish Environmental Protection Agency.

\section{FAO (2014). http://www.fao.org.}

Germ M, Stibilj V, Osvald J, Kreft I (2007). Effect of selenium foliar application on chicory (Cichorium intybus L.). Journal of Agricultural and Food Chemistry, 55: 795-798.

Gökçe R (2000). Hayvancilıkta Mutlak Kar Getiren Yem Silaj. Sütaș, Süt Hayvancılığı Eğitim Merk. Yayınları. Bursa.

İptaș S, Öz A, Boz A (2002a). Tokat-Kazova koșullarında 2. ürün silajılık mısır yetiștirme olanakları. AÜ. Tarım Bilimleri Dergisi, 8(3): 185-191

Kacar B (1995). Plant and soil chemical analysis, III. Soil analysis. University Faculty of Agriculture, Educational Research and Development Foundation Publication No: 3, Ankara.

Kılıç, A (1986). Silo Yemi. Bilgehan Basımevi, BornovaIzmir, s:3-327

Lindsay WL, Norwell WA (1978). Development of DTPA soil test for zinc, iron, manganase and cooper. Soil Science Society of America Jjournal, 42: 422-428.

Longchamp M, Angeli N, Castrec-Rouelle M (2013). Selenium uptake in Zea mays supplied with selenate or selenite under hydroponic conditions. Plant and Soil. 362 (12): 107-117.

Lyons GH, Genc Y, Soole K, Stangoulis J, Liu F, Graham RD (2009). Selenium increases seed production in Brassica. Plant Soil, 318: 73-80.

Olsen SR, Sommers EL (1982). Phosphorus soluble in sodium bicarbonate, methods of soil analysis, part 2, chemical and microbiolojical properties. Edit: A, 1 . page, R, H, Miller, D, R, Keeney, pp. 404-430.

Öner F, Aydın I, Sezer I, Gülümser A, Özata E, Algan D (2011). Bazı silajlık mısır (Zea mays L.) çeșitlerinde verim ve kalite özelliklerinin belirlenmesi. IX. Tarla Bitkileri Kongresi, 1215 Eylül 2011, Bursa.

Özata E, Öz A, Kapar H (2012). Silajlık hibrit mısır çeșit adaylarının verim ve kalite özelliklerinin belirlenmesi, Tarım Bilimleri Araștırma Dergisi, 5 (1): 37-41.

Poldma P, Tõnutare T, Viitak A, Luik A, Moor U (2011). Effect of selenium treatment on mineral nutrition, bulb size, and antioxidant properties of garlic (Allium sativum L.). Journal of Agricultural and Food Chemistry, pp. 54985503.

Rengel Z, Batten GD, Crowley DE (1999). Agronomic approaches for improving the micronutrient density in edible portions of field crops. Field Crop Research, 60: 27-40.

Sajedi N, Ardakani M, Madani H, Naderi A, Miransari M (2011). The effects of selenium and other micronutrients on the antioxidant activities and yield of corn (Zea mays L.) under drought stress. Physiology Molecular Biology of Plants, 17: 215-222.

Sangbom ML, Laurence $\mathrm{IH}$, Michael R, Ross MW, Leon VK, Li L (2005). Molecular and Biochemical Characterization of the Selenocysteine Se-Methyltransferase Gene and SeMethylselenocysteine Synthesis in Broccoli. Plant Physiology, 138 (1): 409-420.

Seppanen M, Turakainen M, Hartikainen H (2003). Seleniım effects on oxidative stres in patato. Plant Science, 165 (2): $311-319$.

Surai PF (2000). Organic selenium: Benefits to animals and humans, a Biochemist's View. Proceedings of the 15th Annual Biotechnolgy in the Feed Industry Symposium. Pp. 205-242.

Pezzarossa B, Piccotino C, Shennan C, Malorgio F (1 999). Uptake and distribution of selenium in tomato plants as affected by genotype and sulfate supply. Journal of Plant Nutrition, 22(10):1613-1635.

TUIK (2008). Türkiye İstatistik Enstitüsü Kurumu Verileri. https://www.tuik.gov.tr/Turakainen M (2007). Selenium 
and its effects on growth, yield and tuber quality in patato. Doctoral thesis, Univercity of Helsinki, Finland.

Tuzuner A (1990). Soil and Water Analysis Handbook. Ministry of Agriculture, Forestry and Rural Affairs General Directorate of Rural Services, Ankara, p. 16.

Yılmaz i (1999). Van koșullarında silajlık mısır yetiștirme olanakları üzerine bir araștırma. GAP I. Tarım Kongresi, 26-28 Mayıs 1999, Șanlıurfa, 703-710s.

Wang J, Wang Z, Mao H, Zhao H, Huang D (2013). Increasing Se concentration in maize grain with soil-or foliarapplied selenște on the Loess Plateau in Chine. Field Crops Research, 150: 83-90.

Xue TL, Hartikainen H (2000). Association of antioxidative enzymes with the synergistic effect of selenium and UV irradiation in enhancing plant growth. Agric Food Sci. Finn., 9: 177-186. 